Disclosure of Interests: None declared

DOI: 10.1136/annrheumdis-2021-eular.2317

\section{POS1355 SYNOVITIS WITH PITTING EDEMA SYNDROME (RS3PE): REVIEW OF TEN YEARS AT A REFERENCE HOSPITAL}

S. Garcia Perez ${ }^{1}$, J. L. Modesto Dos Santos ${ }^{2}$, J. Mendizabal ${ }^{1}$, M. López I Gómez ${ }^{1}$, G. Sada ${ }^{1}$, J. Restrepo Vélez ${ }^{1}$, J. I. Elejalde ${ }^{2}$, L. Garrido Courel $^{1}$, V. Aldasoro ${ }^{1}$, I. Paniagua Zudaire ${ }^{1}$, R. Gutierrez ${ }^{1}$, L. Horcada ${ }^{1}$, F. J. Anniccherico ${ }^{2}$, N. Del Val del Amo ${ }^{1}$, M. C. Fito Manteca ${ }^{1}$, J. Sanchez Alvarez ${ }^{2}$ ${ }^{1}$ Complejo Hospitalario de Navarra (CHN), Rheumatology, Pamplona, Spain; ${ }^{2}$ Complejo Hospitalario de Navarra (CHN), Internal Medicine, Pamplona, Spain

Background: The Remitting Seronegative Symmetrical Synovitis with Pitting Edema Syndrome (RS3PE) is a rare rheumatological disease, considered a benign process.

Objectives: This study aims to describe its clinical features and serological markers, and also to analyze its possible association with neoplasms.

Methods: An observational retrospective study was performed to assess demographic and clinical characteristics of patients diagnosed from RS3PE at a reference hospital amongst the Rheumatology and Internal Medicine departments, from 2010 to 2021.

Results: Twenty-seven patients were included, with a mean age of 82.74 y.o. (IC95\% 80.45-85.04; range 66 to 93), and a $51.85 \%$ proportion of males. Only $22.22 \%$ were from rural areas.

All patients presented bilateral hand edema although some associated feet edema $(40.74 \%)$ or morning stiffness $(70.37 \%)$. Blood tests demonstrated anemia in $44.44 \%$ of patients. Inflammatory markers were elevated, such as C-Reactive Protein (29.23 mg/L, IC95\% 18.17-40.29), erythrocyte-sedimentation rate $(33.74 \mathrm{~mm} /$ hour, IC95\% $24.22-43.26)$ and fibrinogen $(531.6 \mathrm{mg} / \mathrm{dL}$, IC95\% 482.91-580.30). Only a few patients presented any autoimmune serological marker such as antinuclear antibodies $(18.18 \%)$ or rheumatoid factor $(8.70 \%)$ $\mathrm{X}$-ray screening was realized to 22 patients. 14 showed of osteoarthritis radiologic presentation, 4 had radiological findings of chondrocalcinosis and one of them presented both. Only one patient had bone erosion.

Malignancy screening was performed at diagnosis in only $29.63 \%$ of patients (all negative). During follow-up only two tumors were detected (mean accumulated follow-up: 40.37 months, IC95\% 26.70-54.04; range 1 to 122) and there were adenocarcinoma primary neoplasms.

All but one patient received low-dose corticosteroids, with a good and rapid response in all cases. Three patients received treatment with methotrexate (2) or leflunomide (1).

Conclusion: RS3PE must be contemplated in elderly patients presenting with bilateral hand pitting edema and articular symptoms. No specific biomarkers have been described, but inflammatory reaction is often found in the absence of rheumatoid arthritis biomarkers. Rapid response to corticosteroids is prevalent. Only two neoplasms were detected during follow-up.

REFERENCES:

[1] Paira S, Graf C, Roverano S, Rossini J. Remitting seronegative symmetrical synovitis with pitting oedema: a study of 12 cases. Clin Rheumatol. 2002 May;21(2):146-9. doi: 10.1007/pI00011218. PMID: 12086166.

[2] Cobeta García JC, Martínez Burgui J. RS3PE syndrome or benign edematous polysynovitis in the elderly. Study of 8 cases. Rev Clin Esp. 1999 Dec;199(12):785-9. Spanish. PMID: 10687410.

[3] Moreno Obregón F, Del Castillo Madrigal M, Díaz Narváez F, Pérez Delgado FJ. RS3PE syndrome with positive rheumatoid factor. Reumatol Clin. 2019 Nov-Dec;15(6):e168-e169. English, Spanish. doi: 10.1016/j. reuma.2017.11.009. Epub 2017 Dec 15. PMID: 29254743

Disclosure of Interests: None declared

DOI: 10.1136/annrheumdis-2021-eular.2646

\section{POS1356 \\ PERSISTENCE OF TFH CELLS AFTER RITUXIMAB S ASSOCIATED WITH IGG4-RELATED DISEASE RELAPSE}

G. Mancuso $^{1,2}$, T. Jofra ${ }^{3}$, M. Lanzillotta ${ }^{4}$, J. Gerosa $^{3}$, G. DI Colo ${ }^{2}$, L. Dagna ${ }^{2}$ G. Fousteri ${ }^{3}$, E. Della Torre ${ }^{2}{ }^{1}$ Università Vita-Salute San Raffaele, Allergologia ed Immunologia clinica, Milano, Italy; ${ }^{2}$ Ospedale San Raffaele, Immunologia, Reumatologia, Allergologia e Malattie Rare, Milano, Italy; ${ }^{3}$ Università Vita-Salute San Raffaele, Diabetes Research Institute (DRI), Milano, Italy; ${ }^{4}$ Università VitaSalute San Raffaele, Internal medicine, Milano, Italy

Background: Clinical improvement after B-cell depletion with rituxmab suggests a prominent pathogenic role of B-lymphcytes in IgG4-related disease (IgG4-RD). IgG4-RD, however, relapses in most cases together with re-expansion of clonally divergent plasmablasts indicating that treatment with rituximab does not completely abrogates $\mathrm{T}$ follicular helper (Tfh)-cells dependent germinal center reactions leading to de-novo plasmablast differentiation.

Objectives: In the present work we aim to study the effects of B-cell depletion therapy with rituximab on circulating Tfh cells and on the levels of CXCL13 - a chemotactic factor for B-lymphocytes produced by Tfh cells - in patients with IgG4-RD.

Methods: Thirty patients with IgG4-RD, diagnosed according to the "Consensus Statement on the Pathology of IgG4-RD" and fulfilling the "2019 ACR/EULAR Classification Criteria" were included in the present study. Ten patients with relapsing disease were treated with the anti-CD20 monoclonal antibody rituximab (two $1 \mathrm{~g}$ infuxions 15 days apart). Peripheral blood mononuclear cells and serum were collected before rituximab and three months after infusion. Tfh cells subsets in the peripheral blood were measured by flow cytometry and CXCL13 plasma levels were measured by ELISA assay.

Results: No changes in total Tfh cells and Tfh cells subsets were observed three months after rituximab neither in absolute counts nor in percentage of CD4+ T cells. In particular, no difference in Tfh1, Tfh2, Tfh17, T follicular regulatory and highly functional Tfh cells counts was observed before and after treatment. The serum level of CXCL13 was significantly higher in active untreated IgG4-RD patients compared to healthy controls $(151.94 \mathrm{pg} / \mathrm{ml}$ vs $66.98 \mathrm{pg} / \mathrm{ml}, \mathrm{p}$ value $=$ 0.0026 ), but was not affected by rituximab treatment ( $p$ value $=0.41$ ).

Conclusion: In relapsing patients with IgG4-RD rituximab does not affect circulating Tfh cells numbers and serum levels of CXCL13. Persistence of Tfh cells after rituximab and reconstitution of germinal center reactions likely drives IgG4-RD flare.

\section{REFERENCES:}

[1] Lanzillotta M, Mancuso G, Della-Torre E. Advances in the diagnosis and management of IgG4 related disease. BMJ. 2020 Jun 16;369:m1067. doi: 10.1136/bmj.m1067. PMID: 32546500.

[2] Lanzillotta M, Della-Torre E, Stone JH. Roles of Plasmablasts and B Cells in IgG4-Related Disease: Implications for Therapy and Early Treatment Outcomes. Curr Top Microbiol Immunol. 2017;401:85-92. doi: 10.1007/82_2016 58. PMID: 28091934.

[3] Campochiaro C, Ramirez GA, Bozzolo EP, Lanzillotta M, Berti A, Baldissera E, Dagna L, Praderio L, Scotti R, Tresoldi M, Roveri L, Mariani A, Balzano G, Castoldi R, Doglioni C, Sabbadini MG, Della-Torre E. IgG4-related disease in Italy: clinical features and outcomes of a large cohort of patients. Scand $J$ Rheumatol. 2016;45(2):135-45. doi: 10.3109/03009742.2015.1055796. Epub 2015 Sep 23. PMID: 26398142

[4] Mattoo H, Mahajan VS, Della-Torre E, Sekigami Y, Carruthers M, Wallace ZS, Deshpande V, Stone JH, Pillai S. De novo oligoclonal expansions of circulating plasmablasts in active and relapsing IgG4-related disease. J Allergy Clin Immunol. 2014 Sep;134(3):679-87. doi: 10.1016/j.jaci.2014.03.034. Epub 2014 May 6. PMID: 24815737; PMCID: PMC4149918.

Disclosure of Interests: None declared

DOI: 10.1136/annrheumdis-2021-eular.2715

\section{\begin{tabular}{|l|l}
\hline POS1357 & OCULAR SCLERAL PATHOLOGY. UNDERLYING \\
\hline
\end{tabular} DISEASES AND SYSTEMIC TREATMENT. STUDY OF 175 PATIENTS FROM A SINGLE UNIVERSITY CENTER}

L. Sanchez-Bilbao ${ }^{1}$, V. Calvo-Río ${ }^{1}$, J. L. Martín-Varillas ${ }^{2}$, C. Álvarez-Reguera ${ }^{1}$, A. Herrero-Morant ${ }^{1}$, I. González-Mazón ${ }^{1}$, R. Demetrio-Pablo ${ }^{3}$, M. A. GonzálezGay ${ }^{1}$, R. Blanco ${ }^{1} .{ }^{1}$ H.U. Marqués de Valdecilla, Rheumatology, Santander, Spain; ${ }^{2}$ H. Sierrallana, Rheumatology, Torrelavega, Spain; ${ }^{3}$ H.U. Marqués de Valdecilla, Ophthalmology, Santander, Spain

Background: Ocular scleral pathology (OSP) includes episcleritis and scleritis Episcleritis is generally a benign disease with a self-limited course, while scleritis is a more severe ocular condition. In some severe and refractory cases systemic therapy may be required.

Objectives: In a wide series with OSP our aim was to assess a) underlying diseases and $\mathbf{b}$ ) systemic treatment.

Methods: Study of unselected all consecutive patients studied in a single University Hospital during the last ten years with: a) episcleritis and b) scleritis diagnosed by clinical features and slit-lamp (Watson and Hayreh criteria). Best corrected visual acuity (BCVA) and intraocular pressure (IOP) were measured at diagnosis and after systemic treatment.

Results: We studied 175 patients (106 women/ 69 men) /212 affected eyes with OSP (episcleritis $=135$; scleritis $=40$ ); mean age $48.9 \pm 14.2$ years .

OSP was unilateral in $138(78.9 \%)$, recurrent in $74(42.9 \%)$ and chronic in 21 $(12 \%)$. Most of them were idiopathic $(n=81,46.3 \%)$ while associated with IMID were $43.4 \%$ (Table 1). The most important underlying IMID were spondyloarthritis and inflammatory bowel disease, without significant differences between scleritis and episcleritis. Granulomatosis with polyangiits and systemic lupus erythematosus were more frequent in scleritis, not reaching statistical significance. Regarding treatment, topical treatment was used in all patients. $41.1 \%$ received systemic treatment, including systemic glucocorticoids, cDMARDS and 